\title{
Bridging Police Work with the Public Health Domain: An Occupational Safety and Health Perspective
}

\author{
Martin Holzer \\ Institute of Criminal Justice Studies (ICJS), University of Portsmouth, St George's Building, 141 High St, Portsmouth PO1 \\ 2HY, United Kingdom (UK)
}

Corresponding Author Email: martin.holzer@myport.ac.uk

https://doi.org/10.18280/ijsse.100501

Received: 10 July 2020

Accepted: 13 October 2020

\section{Keywords:}

COVID-19, Frontex, Occupational Safety and Health (OSH), police, public health, Security Risk Management (SRM)

\begin{abstract}
For good reasons, public health and public policing constitute two separate constellations of public affairs governance. They widely differ with regard to their objectives, legal basis, workforce, expertise, traditions, occupational culture and many more. In conjunction to both strands of governance Occupational Safety and Health $(\mathrm{OSH})$ - being both a definition and umbrella term - encompasses any kind of activity related to foster the safety and wellbeing of workers. In that regard OSH is marked by being a highly interdisciplinary, hands-on and heuristic undertaken, in particular widely acknowledged of being 'public health-close' and at the same time 'security risk management-near'. That way OSH is clearly identifiable as a highly promising interface bridging police work with public health, in particular by applying mutual theory and language. This conceptual paper proposes a new perspective and view on organisational $\mathrm{OSH}$, functioning well as a legitimate medium for both frontline workers but also managerial functionaries. Viceversa organisational OSH has been identified as a suitable trigger for transferring academic stances into the rather praxis- and realpolitik-driven domain of policing. Alongside the prototypical case study of Frontex operational OSH, OSH has been proven as legitimate driver for utilising the current pandemic COVID-19 outbreak as suitable tool for breaking down existing barriers and silos between the both mentioned strands of governance. That way as additional craft and capacity OSH might enfold truly operational strength and added value.
\end{abstract}

\section{INTRODUCTION}

Since the pandemic outbreak of SARS-CoV-2 (COVID-19) in early 2020, enhanced cross-sectoral response and increasing interdisciplinary cooperation has become both a political priority and a fashionable term in contemporary health and security governance. Even shortly before the COVID-19 crisis, several activities at that moment are or have been funded with the aim to strengthen such cooperation, particularly in the European Union (e.g., EU Healthy Gateways; PROACTIVE EU; Evidence-based best practices on entry/exit screening for infectious diseases in humans etc.).

However, the cross-sectoral approach of cooperation between the police domain and the public health sector in the area of encountering serious cross-border health threats is far from new. Inspired by the early 2000s H5N1 and the 20022004 SARS outbreaks, the International Health Regulation (IHR) of 2005 aiming to develop 'core capacities to effectively respond and improve health security'- finally entered into force on 15 June 2007 - as a novelty equipped the World Health Organization (WHO) from that moment on with the words of Piller (as cited by Fidler) new 'police powers' for controlling outbreaks and came amiss national governments, the so far traditional guardians of public health' [1]. From that moment onwards WHO was able to declare the Public Health Emergency of International Concern (PHEIC) and to recommend health measures to be implemented by the state parties. The declaration of PHEIC related to the COVID-19 pandemic outbreak of 2019-2020 happened on 30 January 2020. Weir and Mykhalovskiy [2] observed the described upgrading of the $\mathrm{WHO}$ as the significant paradigm-shift in international health law.

Several years, some more endemics and with H1N1 of 2009 even one pandemic and PHEIC-declared event later, aimed at improving 'preparedness and coordinate response to health emergencies caused by biological, chemical, environment agents and threats of unknown origin', also the European Union (EU) issued its own legal framework namely Decision 1082/2013/EU on serious cross-border threats to health, aligning EU legislation with the International Health Regulation (IHR) 2005. However, Decision 1082/2013/EU does not build a bridge to the Justice and Home Affairs (JHA) domain at all. It rather contains its competence within the public health domain while bringing up new specific tasks and roles for the European Centre for Disease Prevention and Control (ECDC), as in particular 'covering surveillance, detection and risk assessment of threats to human health from communicable diseases'.

\subsection{Might in particular border policing provide a showcase?}

From the JHA side, in 2006 the coming into force of the Schengen Borders Code as of Regulation (EC) 562/2006 [3] 
setting out the rules on crossing the EU's external borders and the absence of border controls at internal borders was equally significant. With its definition of the 'threat to public health' as relevant for assessing and checking the entry conditions of Third Country nationals to the territory of the EU, for the first time within the EU legislative framework public health and JHA matters became connected, by picking up and explicitly referring to the IHR 2005. In that context it is important to know that by setting out the rules on the border control of persons crossing EU external borders, the Schengen Borders Code theoretically provides border guards with the powers to issue a refusal of entry at the EU external borders due to the consideration of the traveller posing a threat to 'public policy, internal security, public health or the international relations of one or more of the Member States of the European Union' (Art 6) as listed in the 'Standard form for refusal of entry at the border' (Part B) as reason 'I'.

While serious cross-border health threats are already encompassed within border police duties, e.g. during border checks of persons (Art. 8 Schengen Borders Code) or during verifying and assessing the entry conditions for Third-Country nationals (Art. 6 Schengen Borders Code), it is worth looking closer in particular into the situation on the borders and the border policing domain, where the link to public health or even the top-layer international and/or European public health legislation is far more visible than in other police settings.

At the same time important to bear in mind is that the Schengen Borders Code is not only high-level EU legislation directed to EU member states rather than enfolds equally immediate impact on how each and every EU border guard power performs its tasks and duties, e.g., how to conduct border checks or which forms have to be used. Therefore, it becomes equally interesting that the identified public healthborder police hyphen in that context affects and is executed by all levels of border police activities [4], meaning not only by exclusively managerial functionaries (macro level), but also to frontline police officers protecting the borders and applying the Schengen Borders Code daily at the very operational level (meso and micro level).

In the context of the COVID-19 pandemic crisis in particular Art. 6 proved to be vital. For example, during the phase of relaxations of COVID-19 related restrictions and measures at Milan Malpensa airport/Italy - located in the Lombardy region recognised as the first COVID-19 epicentre within Europe in February 2020 - a plane with 125 passengers arriving from Bangladesh via Doha has been refused to enter [5].

When having a closer look at the numbers, according to Frontex data [6] only 3,912 out of in total 223,476 refusals of entries have been issued in whole 2019 to Third Country nationalities due to the listed concerns and considerations of posing a 'potential threat to public policy, internal security, public health or the international relations', which represents only $1.75 \%$ percent of all issued entry bans. In addition, the above-mentioned reasons listed with category 'I' are merged, meaning the de facto reasons for the refusal of entry are not anymore indefinable in the statistics.

COVID-19 in that way seemed to become a catalyst for shedding light on and testing the existing border policingrelated legislative framework and the increased use of it.

\subsection{Risk as an overarching leitmotiv}

Over the last decades the concept of risk became noticeable predominant in almost all areas of society and policy [7] and became one key concern for all types of organisations $[8,9]$. Next to the private sector and the industry where since the 2000s 'Enterprise Risk Management (ERM)' evolved [8], a risk-driven management tendency affected equally also all strands of public administration, including public health and in particular policing [10]. Probably to that reason, also the flagship deliverables as presented by the EU JHA domain are risk based, as for instance Frontex Annual Risk Analysis reports and Europol's threat assessment reports (the Serious Organised Crime Threat Assessment report SOCTA, the Internet Organised Crime Threat Assessment report iOCTA and the EU Terrorism Situation and Trend report TE-SAT).

Of course, JHA activities, police duties, police functions, police workplaces and police culture multi-faceted and are highly diverse $[4,11,12]$. Nevertheless, as prototypical case study alongside of Frontex OSH and in particular looking at border policing this paper might provide a suitable trigger, incentive and transferable approach for other criminal justice settings by 'highlighting a problem locally and identifying good practice elsewhere' [13].

\subsection{Police culture in avoidance of health topics}

Considering the abovementioned identified missing link in topics related to public health and law enforcement, also within the EU legislative framework there might be some room to theorise several issues in regard to why JHA personnel and in particular police officers regularly stay away from public health issues.

Of course, engagement and commitment are always also a matter of each officer's professional performance, expertise and degree of ambition. But it is striking that the cross sectoral cooperation within other domains, as for instance the broad field of military-civilian cooperation (with its so called 'internal-external security nexus') or in police-development activities ('security-development nexus') became illustratively more flourishing than the cooperation with the public health sector in the last years.

All this becomes even more surprising because in theory crime prevention as part of JHA and law enforcement activities also 'draws on experience in public health' [14], where is noted that both "criminology and public health can help locate specific crime prevention practices in a more general context' (pp. 23-24). Examples are given by the analogue classification of primary, secondary and tertiary prevention within public health and crime prevention [14]. Not least in the light of the current discussion about a rigorous police reform in the United States, another example of transferring public health narratives into the criminal justice domain is given by the proposal of the National Police Foundation Board of Directors Chairman Bernard Melekian, who shared his views on implementing 'an emergency medical software program which will guide the 911 response operator through a series of computer-generated questions designed as a triage protocol' [15], in order to deploy each case-related most appropriate and adequate operational means.

However, it is important to keep in mind that while in some criminal justice and police systems the police might be even the driver behind attempts of crime prevention - as for instance in the case of the British Secured by Design (SBD) [14] - prevention is not always necessarily enshrined as part of the criminal justice and police system at all. So, in some criminal justice systems prevention is understood rather as the 
opposite and an alternative to 'law and order' which remains limited to enforcing criminal law.

So, what exactly might be the reason behind that crosssectoral cooperation in the police-public health domain is remaining rudimentary?

\subsubsection{Medical Confidentiality and Secrecy}

Police officers are obviously laypersons in health, not able to differentiate properly between public health and healthcare. For them, both might be identical and on top of that everything about 'medicine' is in addition regularly connoted with some sensitivity and secrecy in regard to dealing with sensitive personal data. Medical confidentiality and even the obligation of physicians and other healthcare professionals to refuse providing information and evidence to law enforcement is a core necessity in Western democratic criminal justice systems. The most recent EU General Data Protection Regulation (GDPR) of 25 May 2018 [16] might have manifested such general awareness and fear regarding possible breaches of data privacy.

\subsubsection{Discipline and power}

For a generally more hierarchically structured organisation such as the police - other than the civilian public health administration - the question of hierarchy and powers becomes inevitably relevant. As described by Eraut [17] there are some occupational groups and especially the more powerful professional groups as in particular medical doctors traditionally seen as 'pure' and 'ideal', while most other professionals and specifically the less powerful ones of the public sector and as in our case the police can be seen as 'semiprofessional' [18]. Therefore, the medical experts of the public health domain might be perceived by officers as powerful academics and 'doctors', always unquestionably highly professional and outside of police officer's capacity to challenge their expertise. As a consequence, it is implied to stay away from deeper discussions with them. In addition, especially public health comes with a longstanding traditions and history at least since the $14^{\text {th }}$ century plague epidemics, contrary to policing, which first originated in the early $19^{\text {th }}$ century and is still an emerging scientific discipline [19], focusing for not more than only a century on contemporary modern civilian police capabilities.

\subsubsection{Two worldviews apart}

Last not least with particular focus on the underlying theoretical foundation, academic paradigms and worldviews, it is important that public health is routed in positivist dominated doctrine, applying quantitative explanations and always relaying on empirics and the prerequisite and understanding that science itself must be necessarily as rigorous, value free and objective as possible [20, 21]. Hereby in the generally quantified dominated world of science qualitative-driven axioms as found in police and security science is often stigmatised as only second-hand option of choice [22], with having only an 'auxiliary role' [23].

On the contrary, policing as part of the criminal justice system tries to solve real-world problems where good practice and knowledge is frequently transferred through 'storytelling' [24] and 'war stories' $[25,26]$. Policing as such therefore is rather nested in the qualitative paradigm affiliated with social science and security, often applying Security Risk Management (SRM) methods, putting emphasis on the human factor and subjective views, thoughts, perceptions and experiences, but also of the situations and context [27, 28].

As a consequence, it is not only that public health protection is not police officer's business where police officers - due to good reasons - are generally not equipped, not sufficiently trained and not possessing the expertise to encounter microorganisms as bacteria or viruses. Moreover, it seems that primarily there are facts and several additional reasons for police representatives - operational and top-level - why they are not being able to think in a similar manner and apply the same language. As a consequence, they might tend to stay away from public health issues.

\section{METHODS AND OBJECTIVES}

As non-empirical conceptual document - backed by a comprehensive literature review - this paper intends to propose and promote bridging the already well developed and existing concepts and narratives of in particular public health, occupational health - fluently intersecting with security risk management - and policing $[29,30]$. That way this paper tries to contribute to better promote the cross-sectoral and interdisciplinary understanding, to provide multi-level insights and to trigger and ideally broaden the scope of managerial job holders' as also policy makers' thinking about a new genuine professional concept [31, 32]

The choice of a non-empirical conceptual framework provides the opportunity of theorisation, unrestricted by the demands of empirical generalisation [33]. While linking public health and policing, but as a true novelty utilising in particular occupational health (OSH) not as a distinct discipline rather as the interface, this paper aims to contribute with an added value to policy and practice and to the general stock of knowledge [31]. That way by applying theory synthesis and integrating previously considered extant distinct concepts [34, 35], this paper might provide a better understanding and should ideally unveil a broader perspective and the 'big picture' [36] when it comes to the interrelation of public health and police work.

The applied concept of this paper is nested in the researcher's background, academic standpoint and of course personal worldviews as a person with different professional backgrounds, on one hand being a researching Professional Doctorate student (DCrimJ) at the Institute of Criminal Justice Studies (ICJS) at the University of Portsmouth/UK, and on the other hand being a Capability Programming Officer at Frontex, the European Border and Coast Guard Agency, where he is exclusively dealing with the implementation and operationalisation of the operational OSH concept as operational capability on its own. In that combined context both endeavours are highly marked by qualitative paradigms, stances and worldviews. Also, and in particular in the researcher's professional world the applied risk managementbased attempt towards safety and health management truly acknowledges the inherent subjectivity and even importance of each actor's individual worldviews running that activity [37, 38].

\section{CASE STUDY: FRONTEX OPERATIONAL OSH IMPLEMENTED UNDER A TRUE 'GOVERNANCE APPROACH'}

Since 2011, but far more predominant after 2015 as the year 
of the so-called peak of the European migration crisis in Europe, several cases of contagious diseases mainly at the most affected Eastern Mediterranean and Western Balkan routes had happened, in particular at registration facilities and at points of first response and entry, triggering the public health issue of and related to newly arriving migrants [39, 40].

The EU, by utilising their Health Programme, responded with funding several Joint Actions (JA) to that upcoming public health issue but reacted primary with strengthening only the primary medical care of the most vulnerable group of newly arriving migrants (e.g. Equi-health with the objective of helping to provide appropriate healthcare to migrants, Rehealth focusing on the integration of newly arrived migrants into the health system and Re-health 2 aiming to implement a personal health record for migrants).

On the other hand, the appearance of contagious diseases became equally an occupational health issue for frontline personnel of the JHA Agencies. So, EASO, Europol, Eurojust and in particular Frontex' operational field staff, which based on the European Council conclusions 25-26 June 2015 became jointly involved in the EU Regional Task Force (EURTF) and mass-migration management activities by implementing the so called Hotspot approach in Greece and Italy [41], was about to establish dedicated first reception facilities 'to better coordinate EU agencies' and national authorities' efforts at the external borders of the EU for the initial reception, identification, registration and fingerprinting of asylumseekers and migrants' [42].

Under the legislative framework applicable at that time, Regulation (EU) 2016/1624, Frontex, the European Border and Coast Guard Agency, 'should have all necessary equipment and staff to be deployed either to regular joint operations or rapid border interventions available and its disposal in several pools' (e.g. European Border and Coast Guard teams, rapid reaction pool, forced-return monitor, forced-return escorts, return specialists). With that pooling approach the vast majority of operationally involved field staff in 2019 have been chosen and directly nominated by the participating EU Member States with the exception of the viewer members of the teams seconded to Frontex, covering with 29,000 man-days which consists only $10 \%$ of the operational activities [43]. As a consequence, (looking at the example of 2019) $90 \%$ of the operational field staff are not employed by Frontex and therefore the Agency had no binding legal obligation of taking care of them.

Nevertheless, following the narrative of Regulation (EU) $2016 / 1624$ in terms of the modus operandi of 'shared responsibility' amongst home, host member states and the Agency, at the same time acknowledging the Duty of Care towards entrusted staff as joint legal-moral-ethical responsibility and obligation, Frontex pro-actively took actions towards the implementation of its own operational Occupational Safety and Health (OSH) policy, finally implemented in January 2018 [43]. The OSH policy from the beginning followed a truly governance approach, which means in that sensitive context of balancing national and EU responsibilities and liabilities for the field staff - highly inspired by Security Risk Management (SRM) and integrating health promotion into workplace OSH policies [44] - that the focus was put on organisational culture and in this case promoting personal and organisational risk and safety culture $[44,45]$. That approach has been already proofed as having the strongest influence over workplace safety and health [46-48].

In the context of developing Frontex OSH, the approach of the International Labour Organization (ILO) of 'SOLVE: Integrating Health Promotion into Workplace OSH policies' [44] became increasingly relevant, because border guards and other frontline workers at the EU's external borders are engaged in exactly that thin blurred line and area where public health merges and coincides with their individual and occupational health (Figure 1):

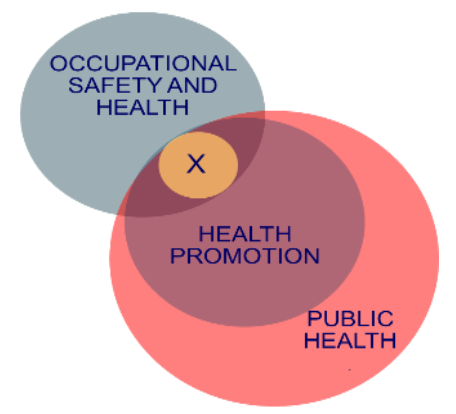

Figure 1. Workplace health promotion and OSH [44]

Frontex OSH is fully in line with the EU governance principle of subsidiarity as of Article 5 of the Treaty on European Union [49], which is based on the good faith cooperation and good interplay between host and home Member States national authorities and actors, meaning the Agency itself, the communities where the operational activities take place and the individual responsibility of each and every participant in the operational activities $[45,50]$.

Next to the above mentioned collective preventative mode, work-related stress and psychological factors have been equally put at Frontex OSH's forefront. With putting into force of Frontex' own Mental Health Strategy [51] the focus was equally laid on work-related and cumulative stress as one of the biggest health and safety challenges faced by the operational staff in Europe today [52]

\section{RESULTS}

Since Frontex obviously does not have any health or medical department at its disposal, based on the authors academic and professional background in the field of Criminal Justice and Security Risk Management (SRM), the development of Frontex Occupational Safety and Health (OSH) capabilities was mainly guided and built up by following the principles of Security Risk Management (SRM). This flexible and qualitative approach was used in the development of OSH; however, it has sustained by clear methodology and by applying scientific-near meaning heuristics and rule-of thumb approaches [37].

The development of Frontex Mental Health Strategy [51] might provide a good and illustrative example of such methodologically clear and heuristic approach. As initial starting point, Frontex commissioned two explorative field studies in order to assess relevant mental health factors and specifically psychological hazards amongst deployed field staff. With the two studies 'Frontex OSH Mental Health Factors: A preliminary study' [53]' and 'Keeping our Border Guards mentally healthy: An explorative study on management tools for personnel care' [51, 54], a strong scientific foundation has been established, both identifying potential prevalent mental health threats as starting points. Both studies deployed semi-structured interviews in a 
qualitative research design. Based on their findings a questionnaire in a quantitative survey format has been addressed to all Frontex national partner authorities [51], in order to understand and to assess national capabilities and strategies in that domain. After identifying those EU Member States possessing the most advanced or as most innovative assessed expertise in mental health topics, as a final step a working level expert's workshop has been organised providing final corroboration and supporting the ultimate draft of the strategy paper [51].

Another good example for engaging external but intentionally always academic expertise, is the development of Frontex Recommended Vaccination Scheme (RVS) for personnel assigned to coordinated operational activities of the European Border and Coast Guard [50]. This exercise was in the same manner as Frontex Mental Health Strategy based on an initial explorative survey on existing recommendations or requirements for vaccinations for deployed resources, assigned by the national partner authorities and EU Member States. This research was also conducted by a highly respected academic and active researcher [55], in addition flanked by contribution of the European Centre for Disease Prevention and Control (ECDC).

\subsection{Successful testimonies and synergies}

Shortly after its implementation and after delivering first tangible outputs, Frontex Occupational Safety and Health (OSH) policy experienced increasing interest within the EU JHA domain. Frontex originally named 'Health and Safety Guidelines' of 2018 became further developed and finally cobranded by the European Asylum Support Office (EASO) and the European Union Agency for Law Enforcement Cooperation (Europol) as 'Occupational Health and Safety Deployment Information' [45]. The first edition was initially published in 2019. In addition, under the European Commission funded and Frontex-led programme 'EU4BorderSecurity', Frontex OSH became the driver for discussing with the EU Southern Neighbourhood the way to effectively address issues of public health, internal security, health and safety of personnel, preparedness and crisismanagement at the borders (European Commission. Directorate-General for European Neighbourhood Policy and Enlargement Negotiations, Regional South Newsletter 19 June 2020). The question is: what is and was finally the key factor for that success and the transferability of Frontex' approach?

\subsubsection{Security and securitization as foundation for a common language}

With specific view to JHA matters and border policing in particular, in the aftermath of 9/11 a classical securitisation process was being played out 'where EU institutions started making clear links between terrorism, security, migration and borders' [56]. Securitisation in that regard according to The Copenhagen School describes a process 'by which any issues are made into security issues through securitizing speech acts' [57]. The same securitization process which has been identified in the JHA domain became equally criticised to have happened also in the public health domain, where -as mentioned in the introduction - Weir and Mykhalovskiy [2] with the empowerment of the WHO see a true epistemological paradigm shift. Hanrieder and Kreuder-Sonnen [58] are going further and describe a sort of 'emergency trap', where the securitization of crisis and public health governance since the
2003 SARS pandemic and further with the 2009 swine influenza are seen as drivers of the exaggerated and further securitization of any other 'further issues'.

\subsubsection{ISO 45100:2018 and the contemporary Momentum of $\mathrm{OSH}$}

With the new ISO 45001:2018 just recently a universal OSH framework has been established, specifying requirements for Occupational Safety and Health Management Systems (OSHM) and providing guidance for its use in order to enable organizations to provide safe and healthy workplaces as well as by proactively improving its OSH performance.

ISO 45001:2018 is truly based on risk assessment and hazard identification. Next to promoting the iterative four-step PDCA management concept cycle ('plan-do-check-act'), the core pillar of ISO 45001:2018 is the provision and introduction of a five-level model of the hierarchy of controls, consisting of (Figure 2):

- Elimination - which means modifying the workplace design to eliminate the hazard; e.g., introduce mechanical lifting devices to eliminate the manual handling hazard;

- $\quad$ Substitution - which means substituting a hazardous material with a less hazardous material or reducing the system energy (e.g., lower the force, amperage, pressure, temperature, etc.);

- $\quad$ Engineering controls - meaning for instance to install ventilation systems, machine guarding, interlocks, sound enclosures, etc.;

- Signage, warnings, and/or administrative controls which means for example deploying safety signs, hazardous area marking, photo-luminescent signs, markings for pedestrian walkways, warning sirens/lights, alarms, safety procedures, equipment inspections, access controls, safe systems of working, tagging, and work permits, etc.;

- Personal protective equipment (PPE) - meaning the deployment of safety glasses, hearing protection, face shields, safety harnesses and lanyards, respirators, or gloves.

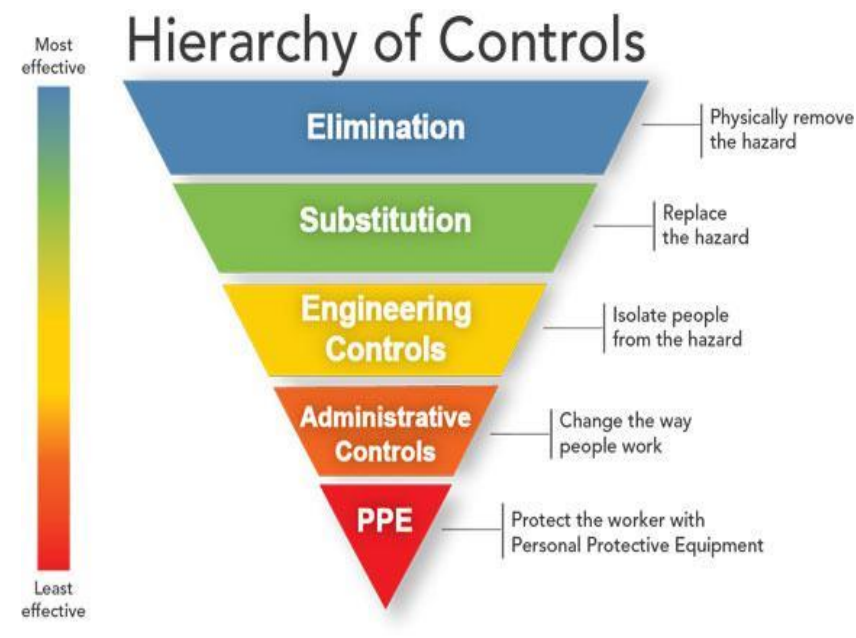

Figure 2. Hierarchy of controls, displayed as an inverted pyramid (NIOSH)

Source: Centers for Disease Control and Prevention (CDC). Retrieved from https://www.cdc.gov/niosh/topics/hierarchy/default.html 
Occupational Safety and Health (OSH) in particular for the law enforcement sector and policing within Europe, underlined by high-level related framework legislation and adjuvant jurisprudence (e.g. Working Time Directive 2003/88/EC; Safety and Health of Workers Directive 89/391/EEC; UK Police Health and Safety Act 1997; UO v Készenléti Rendőrség C-211/19 2020) [59-62], with the same rhythm as the previously described securitisation processes since the early 2000s experienced two quite dynamic decades. Meanwhile OSH-related-research pierces through almost all types of police officer's workplace settings, arousing the suspicion that an axiom progresses of conglomerating excessively more and more OSH-measures for controlling workplace risks, or in the ideal stance to completely 'risk them out' [63]. Thus, a literature research provides us numerous examples from all around the world on police related occupational safety and health issues as for instance on the ergonomic evaluation during patrol duties [64], risk factors in crashes involving on-duty police cars [65], work absence and perceived stress caused by on-duty nonfatal injuries [66], public safety and security worker's potential Occupational Hepatitis-B virus exposure [67] or secondary trauma of police officers working with traumatized victims [68].

\subsubsection{The ISO 45001:2018-crime prevention nexus}

With specific view to hazard control in the sense of ISO 45011:2018, several parallels in regard to contemporary approaches and debates of crime prevention and crime reduction strategies can be noted. In the same manner as ISO 45001:2018s approach of elimination of hazards though modifying the workplace design, also in the remit of crime prevention, design features already since the 1950s became intentionally deployed to prevent crime [69, 70]. Meanwhile this idea became more conceptualised and enshrined in the gradually emerging approach of Crime Prevention through Environmental Design (CPTED) [71-73], e.g. by alley gating or street lighting initiatives. Both OSH hazard control as also CPTED are mainly based on the underpinning rational choice theory [74], emphasizing on the decision-making process of the individual and how environmental measures might influence his/her behaviour.

When it comes to substitution and engineering controls of hazards, parallels can be equally drawn to the approach of Situational Crime Prevention (SCP). In particular by applying the rational choice theory and by influencing individual's behaviour by changing either the context or the environment on which those decisions to commit a crime are made. Therefore, SCP is able to make the offence less possible [75, 76]. In the contextual matter for example Clarke [77] reports that in Germany during the 1980s motorcycle thefts declined as a result of the requirement to wear a crash helmet which substantially increased the risk to offenders being identifiable because of the fact of being unable to steal a motorcycle and a crash helmet at once. Environmental changes in terms of SCP aiming to influence the decision-making process of the potential offender are the use of security hardware and technology, e.g. locks, bolts, CCTV or alarms.

\section{DISCUSSION AND CONCLUSIONS}

As presented by this non-empirical conceptual paper, routed both in tacit professional expertise together with utilising scientific methods and the academic language of research, it seems highly legitimate - as a true novelty and innovative identifiable path - to utilise and to promote risk based Occupational Safety and Health (OSH) as well functioning police-public health interface.

Rather than starting to connect the dots from the theoretical and/or high-level policy level, it seems also much more advisable to follow the well-established OSH principle of right-dosed 'sufficiency' [78] and starting the exercise intentionally from bottom-up.

Promoting $\mathrm{OSH}$ and in particular workplace health promotion by departing from the area of border policing precisely tipping onto the blurred intersection of public health and occupational health - might provide us with a new outset for a better understanding and cooperation amongst public health experts and practitioners and public security and safety personnel as such.

As presented, applying $\mathrm{OSH}$ in addition might offer the utilisation of ISO 45001:2018 narrative and terminology with its in particular rational-choice approach, obviously nested in criminology.

Also, when it comes to language, applying the qualitative driven OSH narrative and terminology because of being rooted in the identification of risks, threats, hazards and dangers [79], $\mathrm{OSH}$ terminology is rather easily understood and more accessible by law-enforcement in contrary to the highly quantitative medical axiom and language.

On the other hand, and as illustrative seen with the example and prototypical case study of Frontex OSH, OSH might become a suitable trigger and carrier also for transferring academic stances - in particular in terms of theorisation and following clear methodology - into the more praxis- and realpolitik-driven JHA and law enforcement domain.

During the ongoing pandemic event the rise of OSH-related publications steaming from law enforcement [80-82] vividly indicates that it seems feasible that the call of this paper becomes heard.

\section{BIOGRAPHICAL NOTE AND AFFILIATIONS}

The author has been a police practitioner since 1993 and has extensive experience in both regular police work and border policing. At this moment he holds a Chief Inspectors rank in the German Federal Police. Since 2015 he has been seconded to Frontex, the European Border and Coast Guard Agency, where he is exclusively responsible for the Occupational Safety and Health (OSH) concept at the operational field layer at the EU's external borders. The author possesses an academic degree (Diploma) in public administration from the Federal University of Applied Administrative Sciences of Germany, a master's degree (MA) in Criminal Justice (MACRIMGOV) awarded by the Ruhr University Bochum (RUB)/Germany and a Postgraduate Certificate (PGCert) awarded with Merit in Security and Risk Management (SRM) from the University of Leicester/UK. As a researching professional he pursues at the moment the Professional Doctorate in Criminal Justice (DCrimJ) at the Institute of Criminal Justice Studies (ICJS) at the University of Portsmouth/UK. His research focuses on potentially overlooked aspects of $\mathrm{OSH}$ in the remit of policing, specifically on the correlation and the causal explanation of potential adverse effects of exaggerated duty of care. 


\section{REFERENCES}

[1] Fidler, D.P. (2004). Beyond China: Lessons from SARS for post-Westphalian public health. SARS, Governance and the Globalization of Disease, London: Palgrave Macmillan, $132-155$ https://doi.org/10.1057/9780230006263_7

[2] Weir, L., Mykhalovskiy, E. (2010). Global Public Health Vigilance: Creating a World on Alert. New York: Routledge.

[3] Regulation (EC) 562/2006 of the European Parliament and of the Council of 15 March 2006 establishing a Community Code on the rules governing the movement of persons across borders (Schengen Borders Code).

[4] Benyon, J., Turnbull, J.L., Willis, A., Woodward. R. (1994). Understanding police cooperation in Europe: Setting a framework for analysis. In: Anderson, M. and Den Boer, M., ed., Policing Across National Boundaries, London: Pinter, 46-65.

[5] Di Ilaria, C. (2020). Coronavirus, volo dal Bangladesh con 40 passeggeri arriva a Malpensa: niente sbarco, saranno direttamente rimpatriati [Coronavirus, flight from Bangladesh with 40 passengers arrives at Malpensa: no disembarkation, they will be directly repatriated]. La Repubblica, 8 July [online]. Available from https://milano.repubblica.it/cronaca/2020/07/08/news/co ronavirus aereo bangladesh malpensa passeggeri non sbarcano rimpatrio-261316842/?ref=fbpr, accessed on July $1,2020$.

[6] Frontex (2020a). Risk Analysis for 2020. Luxemburg: Publication Office of the European Union.

[7] Beck, U. (1992). Risk Society. London: SAGE.

[8] Merna, T., Al-Thani, F. (2005). Corporate Risk Management. London: J. Wiley and Sons.

[9] Wakefield, A. (2014). Corporate security and enterprise risk management. In: Walby, K. and Lippert, R., ed., Corporate Security in the 21 st century: Theory and Practice in International Perspective. Basingstoke: Palgrave Macmillan. https://doi.org/10.1057/9781137346070_13

[10] Achim, A.C. (2014). Risk management issues in policing: From safety risks faced by law enforcement agents to occupational health. Procedia Economics and Finance, 15: 1671-1676. https://doi.org/10.1016/S22125671(14)00639-X

[11] Mawby, R.I. (2000). Core policing: The seductive myth. In: Leishman, F., Loveday, B. and Savage, S., ed., Core issues in policing 2nd ed., 107-123. Harlow: Longman.

[12] Mawby, R.I., ed. (1999). Policing Across the World: Issues for the Twenty-First Century. London: UCL Press.

[13] Pakes, F. (2019). Comparative Criminal Justice 4th Edition. London: Routledge.

[14] Sutton, A., Cherney, A., White, R. (2014). Crime Prevention 2nd Edition. Cambridge: Cambridge University Press.

[15] Burgess, T., Melekian, B. (2020). We must reform our police. Here's how. Crosscut, 23 June. Available from https://crosscut.com/2020/06/we-must-reform-ourpolice-heres-

how?fbclid=IwAR3RPI3auECvPmj4XviPQST1 xhKSp7 SKIRqLnHfHU6VqZq4Eq8w8F39wmuI, accessed on July 19, 2020.

[16] Regulation (EU) 2016/679 of the European Parliament and of the Council of 27 April 2018 on the protection of natural persons with regard to the processing of personal data and on the free movement of such, data and repealing Directive 95/46/EC (General Data Protection Regulation).

[17] Eraut, M. (1994). Developing Professional Knowledge and Competence. London: Falmer Press.

[18] Etzioni, A. (1969). The Semi Professions and their Organization. New York: Free Press.

[19] Nägel, C., Vera, A. (2020). Police science as an emerging scientific discipline. International Journal of Police Science \& Management, 22(3): 1-11. https://doi.org/10.1177/1461355720917413

[20] Bryman, A. (2016). Social Research Methods $5^{\text {th }}$ Edition. Oxford: Oxford University Press.

[21] Gilbert, N., Stoneman, P. (ed.) (2016). Researching Social Life 4th Edition. Thousand Oaks, CA: Sage.

[22] Public Safety Canada (2012). Building a Safe and Resilient Canada: All Hazards Risk Assessment Methodology Guidelines 2012-2013. Ottawa: Her Majesty the Queen in Right of Canada.

[23] Howe, K.R. (2004). A critique of experimentalism. Qualitative Inquiry, 10(1): 42-61. https://doi.org/10.1177/1077800403259491

[24] Rantatalo, O., Karp, S. (2018). Stories of Policing: The Role of Storytelling in Police Students' Sensemaking of Early Work-Based Experiences. Vocations and Learning, 11(1), 161-177 [online]. Available from http://search.ebscohost.com/login.aspx?direct=true \&db $=$ eric $\& A N=E J 1171258 \&$ site $=$ eds-live, accessed on July 16,2020

[25] Van Maanen, J. (1973). Observations on the making of policemen. Human Organization, 32(4): 407-418. https://doi.org/10.17730/humo.32.4.13h7x81187mh8km 8

[26] Van Maanen, J. (1975). Police organization: A longitudinal examination of job attitudes in an urban police department. Administrative Science Quarterly, 20(2): 207-228. ttps://doi.org/10.2307/2391695

[27] Creswell, J.W. (2003). Research Design: Qualitative, Quantitative, and Mixed Methods Approaches. 2nd Edition. Thousand Oaks, CA: Sage.

[28] Willis, W., Jost, M., Nilakanta, R. (2007). Foundations of Qualitative Research: Interpretive and Critical Approaches. Thousand Oaks, CA: Sage.

[29] Brooks, D.J. (2013). Corporate security: Using knowledge construction to define a practicing body of knowledge. Asian Journal of Criminology, 8: 89-101. https://doi.org/10.1007/s11417-012-9135-1

[30] Smith, C.L., Brooks, D.J. (2013). Security Science: The Theory and Practice of Security. Waltham, MA: Elsevier.

[31] Gilson, L.L., Goldberg, C.B. (2015). Editors' comment: So, what is a conceptual paper? Group \& Organization Management, 40(2):

127-130. https://doi.org/10.1177/1059601115576425

[32] Philips, E., Pugh, D. (1994). How to Get a PhD 2nd Edition. Buckingham: Open University Press.

[33] Vargo, S.L., Lusch, R.F. (2004). Evolving to a new dominant logic for marketing. Journal of Marketing, 68(1): 1-17. https://doi.org/10.1509/jmkg.68.1.1.24036

[34] Jaakkola, E. (2020). Designing conceptual articles: four approaches. AMS Review, 10: 18-26. https://doi.org/10.1007/s13162-020-00161-0

[35] MacInnis, D.J. (2011). A framework for conceptual contributions in marketing. Journal of Marketing, 75(4): 
136-154. https://doi.org/10.1509/jmkg.75.4.136

[36] Delbridge, R., Fiss, P.C. (2013). Editors' comments: Styles of theorizing and the social organization of knowledge. Academy of Management Review, 38(3): 325-331. https://doi.org/10.5465/amr.2013.0085

[37] Waring, A. (2013). Corporate Risk and Governance: And end to Mismanagement, Tunnel Vision and Quackery. London: Routledge.

[38] Waring, A., Glendon, A. (1998). Managing Risk 1st Edition. London: Cengage Learning.

[39] Boudville, D.A., Joshi, R., Rijkers, G.T. (2020). Migration and tuberculosis in Europe. Journal of Clinical Tuberculosis and Other Mycobacterial Diseases, 18: 100143. https://doi.org/10.1016/j.jctube.2020.100143

[40] European Centre for Disease Prevention and Control (2015). Rapid risk assessment: Communicable disease risks associated with the movement of refugees in Europe during the winter season, 16 November 2015. Luxembourg: Publication Office of the European Union.

[41] Leonard, S., Kaunert, C. (2019). Refugees, Security and the European Union. Milton Park: Routledge.

[42] European Parliament (2018). Hotpots at EU external borders: state of play. Available from https://www.europarl.europa.eu/RegData/etudes/BRIE/ 2018/623563/EPRS_BRI(2018)623563_EN.pdf., accessed August 1, 2020.

[43] Frontex (2020b). Annual Information on the Commitments and Deployments of the Member States to the European Border and Coast Guard Teams and the Technical Equipment Pool: Report on the operational resources in 2019. Luxembourg: Publications Office of the European Union.

[44] International Labour Organization (ILO). (2012). SOLVE: Integrating Health Promotion into Workplace OSH policies: Participant's workbook. Geneva: International Labour Office.

[45] EASO, Europol, Frontex, 2020. Occupational Health and Safety - Deployment Information. Luxemburg: Publication Office of the European Union.

[46] Chib, S., Kanetkar, M. (2014). Safety culture: The buzzword to ensure occupational safety and health. Procedia Economics and Finance, 11: 130-136. https://doi.org/10.1016/S2212-5671(14)00183-X

[47] European Agency for Safety and Health at Work, 2020. Mission and vision [online]. Available from https://osha.europa.eu/en/about-eu-osha/what-wedo/mission-and-vision, accessed on July 15, 2020.

[48] Glendon, A.I., Stanton, N.A. (2000). Perspectives on safety culture. Safety Science, 34: 193-214.

[49] OJ No. C 326, 26.10.2012, p. 20.

[50] Frontex (2019). Frontex Recommended Vaccination Scheme (RVS) for personnel assigned to coordinated operational activities of the European Border and Coast Guard. 1st Edition. Luxemburg: Publication Office of the European Union.

[51] Frontex (2018). Frontex Mental Health Strategy. Luxembourg: Publications Office of the European Union.

[52] Mullins, L. (2013). Management \& Organizational Behaviour 10th Edition. Harlow: Pearson.

[53] Storey, A. (2017). Frontex OSH Mental Health Factors: A preliminary study. Luxemburg: Publication Office of the European Union.

[54] Wolf, P. (2017). Keeping our Border Guards mentally healthy: An explorative study on management tools for personnel care. Unpublished thesis (Joint Master's in Strategic Border Management). University of Salamanca.

[55] D’Ancona, F. (2019). National vaccination schemes and applicable strategies in the framework of participation in Frontex coordinated activities. Luxembourg: Publication Office of the European Union.

[56] Neal, A. (2009). Securitization and risk at the EU border: The origins of FRONTEX. Journal of Common Market Studies, 47(2): 333-356. https://doi.org/10.1111/j.14685965.2009.00807.x

[57] Georgiadou, C., Bouquet, J. (2014). How to do more with less: FRONTEX and CSDP, an unexpected golden couple? Bridging Europe Policy Brief.

[58] Hanrieder, T., Kreuder-Sonnen, C. (2014). WHO decides on the exception? Securitization and emergency governance in global health. Security Dialogue, 45(4): 331-348. https://doi.org/10.1177/0967010614535833

[59] Council Directive of 12 June 1989 on the introduction of measures to encourage improvements in the safety and health of workers at work

[60] Directive 2003/88/EC of the European Parliament and of the Council of 4 November 2003 concerning certain aspects of the organisation of working time.

[61] Police Health \& Safety Act (1997) 42.

[62] UO v Készenléti Rendőrség (2020) C-211/19.

[63] Ricciardelli, R. (2018). Risk it out, risk it out: Occupational and organizational stresses in rural policing. Police Quarterly, 21(4): 415-439. https://doi.org/10.1177/1098611118772268

[64] Cardoso, M., Girouard, M., Callaghan J., Albert, W. (2017). An ergonomic evaluation of city police officers: An analysis of perceived discomfort within patrol duties. International Journal of Occupational Safety and Ergonomics, 23(2): 175-184. https://doi.org/10.1080/10803548.2016.1249728

[65] Chu, H.C. (2015). Risk factors for the severity of injury incurred in crashes involving on-duty police cars. Traffic Injury Prevention, 17(5): 495-501. https://doi.org/10.1080/15389588.2015.1109082

[66] West, C., Fekedulegn, D., Andrew, M., Burchfield, C.M., Harlow, S., Bingham, C.R., McCullagh, M., Park, S.K., Violanti, J. (2017). On-duty nonfatal injury that lead to work absences among police officers and level of perceived stress. Journal of Occupational and Environmental Medicine, 59(11): 1084-1088. https://doi.org/10.1097/JOM.0000000000001137

[67] Averhoff, F., Moyer, L., Woodruff, B., Deladisma, A., Nunnery, J., Alter, M., Margolis, H. (2002). Occupational exposures and risk of hepatitis B virus infection among public safety workers. Journal of Occupational and Environmental Medicine, 44(6): 591596. https://doi.org/10.1097/00043764-20020600000024

[68] Foley, J., Massey, K.L.D. (2020). The 'cost' of caring in policing: From burnout to PTSD in police officers in England and Wales. The Police Journal: Theory, Practice and Principles, $1-18$. https://doi.org/10.1177/0032258X20917442

[69] Jacobs, J. (1961). The death and life of great American Cities. New York, NY: Vintage Books.

[70] Newman, O. (1972). Defensible space; crime prevention through urban design. New York, NY: Macmillan.

[71] Armitage, R. (2013). Crime prevention through housing design. Basingstoke: Palgrave. 
[72] Clarke, R.V. (1992). Situational crime prevention successful case studies. New York, NY: Harrow and Heston.

[73] Coleman, A.M. (1985). Utopia on trial: Vision and reality in panned housing. London: Hilary Shipman.

[74] Cromwell, P.F., Olson, J.N., Avary, D.W. (1991). Breaking and entering: An ethnographic analysis of burglary. Studies in Crime, Law, and Justice, Volume 8.

[75] Cornish, D., Clarke, R.V. (ed.) (2014). The Reasoning Criminal: Rational Choice Perspectives on Offending. New Brunswick, NJ: Transaction Publishers.

[76] Tilley, N., Farrell, G. (2012). The reasoning criminologist: essays in honour of Ronald V. Clarke. Abingdon: Routledge.

[77] Clarke, R.V. (2010). Situational crime prevention successful case studies 2nd Edition. Boulder, CO: Lynne Rienner.

[78] Brown, G.C. (2010). The principle of sufficiency and the evolution of control: Using control analysis to understand the design principles of biological systems. Biochemical Society Transactions, 38(5): 1210-1214.
https://doi.org/10.1042/BST038121

[79] Aven, T. (2015). Risk assessment and risk management: Review of recent advances on their foundation. European Journal of Operational Research, 253(1): 1-13. https://doi.org/10.1016/j.ejor.2015.12.023

[80] INTERPOL (2020). COVID-19 Pandemic: Guidelines for Law Enforcement [online]. Available from https://www.interpol.int/en/News-and-

Events/News/2020/INTERPOL-issues-internationalguidelines-to-support-law-enforcement-response-toCOVID-19, accessed on July 15, 2020.

[81] International Security and Emergency Management Institute (ISEM) (2020). Guidance for Police and Gendarmerie Officers: How to Protect Yourself in Coronavirus Risky Environments. Bratislava: ISEM Institute.

[82] United Nations Office on Drugs and Crime UNODC (2020). Law Enforcement Response to COVID-19 Pandemic. Tashkent: UNODC Regional Office for Central Asia. 